\title{
Produksi Kelapa Sawit (Elais guineensis Jacq.) Dengan Peremajaan Tumbang Total dan Sisipan
}

\author{
${ }^{1}$ Nasamsir dan ${ }^{2}$ Edi Romadoni \\ ${ }^{1}$ Program studi Agroteknologi, Fakultas Pertanian Universitas Batanghari \\ ${ }^{2}$ Alumni Program studi Agroteknologi, Fakultas Pertanian Universitas Batanghari \\ Jl. Slamet Riyadi-Broni, Jambi. 36122. Telp. +62074160103 \\ *e-mail korespondensi : nasamsirsamsir@yahoo.co.id
}

\begin{abstract}
This study aims to determine the production of oil palm with a different replanting system. The study was conducted in the area of total fall replanting system and underplanting system area located in Panca Mulya Village, Sungai Bahar District, Muaro Jambi Regency. The material used in this study was the Tenera variety of oil palm plants aged 4.5 years and 5.5 years. The study used a survey method with systematic sampling method. The main variables observed were plant production as well as additional variables ; physical plant, soil pH, light intensity, temperature, and humidity. The results showed that the replanting system significantly affected the production of oil palm plants a, plant hight $(102.88 \mathrm{~cm})$, stem circumference $(2.35 \mathrm{~m})$, leaf color (light green), soil pH, light intensity, temperature, and air humidity. Palm oil crop production is higher in areas with total fall replanting systems.
\end{abstract}

Keywords: replanting system, oil palm

Abstrak. Penelitian ini bertujuan untuk mengetahui produksi kelapa sawit dengan sistem peremajaan yang berbeda. Penelitian dilaksanakan di areal peremajaan sistem tumbang serempak dan areal sistem peremajaan sisipan yang terdapat di Desa Panca Mulya kecamatan Sungai Bahar Kabupaten Muaro Jambi. Bahan yang digunakan dalam penelitian ini adalah tanaman kelapa sawit varietas Tenera berumur 4,5 tahun dan 5,5 tahun. Penelitian menggunakan metode survey dengan metode pengambilan sampel systematic sampling. Peubah utama yang diamati adalah produksi tanaman serta peubah tambahan ; fisik tanaman, $\mathrm{pH}$ tanah, intensitas cahaya, suhu, dan kelembaban. Hasil penelitian menunjukkan sistem peremajaan berpengaruh nyata terhadap produksi tanaman kelapa sawit dan tinggi tanaman $(102,88 \mathrm{~cm})$,lingkar batang $(2,3507 \mathrm{~m})$,warna daun (hijau muda), $\mathrm{pH}$ tanah, intensitas cahaya, suhu, serta kelembaban udara. Produksi tanaman kelapa sawit lebih tinggi pada areal dengan sistem peremajaan tumbang serempak.

Kata Kunci : sistem peremajaan, kelapa sawit

\section{PENDAHULUAN}

Tanaman kelapa sawit (Elaeis guinensis Jacq.) termasuk kedalam golongan famili Arecaceae, penghasil minyak nabati yang memiliki banyak manfaat dari turunannya antara lain minyak makan, minyak industri dan biodiesel (bahan bakar nabati). Kelapa sawit sangat diminati untuk dikelola sebagai sumber andalan minyak nabati dan bahan agroindustri (Sukamto, 2008)

Kelapa sawit merupakan tanaman perkebunan penting di Indonesia, termasuk Jambi. Indonesia menyumbang $48 \%$ produksi CPO internasional. Ada tiga bentuk pengusahaan kelapa sawit di Indonesia, Perkebunan Negara (PN), Perkebunan Besar Swasta (PBS) dan perkebunan rakyat. Perkebunan rakyat yang dikelola secara perseorangan produktivitasnya masih rendah. Mutu bibit, kultur teknis, dan faktor eksternal akan mempengaruhi pertumbuhan dan produktivitas kelapa sawit

Peningkatan pertambahan luas lahan pengusahaan kelapa sawit dari tahun ke tahun berdampak pada peningkatan produksi kelapa sawit di Indonesia (Nasution,Hanum, dan Ginting, 2014). Perkebunan kelapa sawit di Indonesia mencapai 14,3 juta hektar, dengan sebaran ; perkebunan rakyat seluas 5,8 juta hektar (41\%), Badan Usaha Milik Negara (BUMN) mencapai 715 ribu hektar (5\%), dan sisanya adalah perkebunan swasta (54\%). Perkebunan rakyat menyumbangkan 14 juta ton CPO (33\%), perkebunan Negara 2,5 juta ton CPO (6\%), perkebunan swasta memproduksi kelapa sawit sebesar 26,5 juta ton CPO (61\%) ("Direktorat Jenderal Perkebunan, Kementerian Pertanian, 2018").

Menurut Sukamto (2008), peningkatan produksi kelapa sawit Indonesia adalah akibat dari perluasan areal tanam, bukan karena peningkatan produktivitas. Rendahnya produktivitas tanaman kelapa sawit nasional (15 ton TBS per ha ${ }^{-1}$ tahun $^{-1}$ ) dibanding Malaysia (25 ton TBS ha ${ }^{-1}$ tahun $^{-1}$ ) memerlukan upaya perbaikan mulai dari persiapan benih, pembibitan, peremajaan, pengelolaan tanaman belum menghasilkan sampai pengelolaan tanaman menghasilkan.

Tanaman kelapa sawit yang telah melewati umur ekonomis (> 25 tahun) kemampuan produksinya yang sudah menurun, hanya sekitar 14 ton TBS ha-1 tahun $^{-1}$ perlu diremajakan.

Sistem peremajaan dapat dilakukan dengan beberapa metode dengan kelemahan dan kelebihan masing-masing sistem, seperti serangan hama kumbang tanduk, penyakit Ganoderma, serta pertimbangan ekonomi bagi petani pengelola kebun. 
Nasamsir dan Edi Romadoni. Produksi Kelapa Sawit (Elais guineensis Jacq.) Dengan Peremajaan Tumbang Total dan Sisipan

Berdasarkan hal-hal yang telah diuraikan di atas, maka perlu dilakukan kajian tentang produksi kelapa sawit yang menerapkan sistem peremajaan tumbang serempak dan sistem peremajaan sisipan.

\section{METODE PENELITIAN}

Penelitian dilakukan di perkebunan kelapa sawit rakyat yang terletak di Unit 3 Desa Panca Mulya Kecamatan Sungai Bahar Kabupaten Muaro Jambi. Penelitian ini dilaksanakan pada bulan Juni sampai dengan bulan Juli 2019.

Alat yang digunakan dalam penelitian ini adalah, Global Positioning System, ph meter tanah, kamera, lux meter, hygrometer, meteran, termometer dan timbangan kelapa sawit. Bahan bahan yang digunakan dalam penelitian ini adalah tanaman kelapa sawit areal replating sisipan yang berumur 5,5 tahun dan tanaman kelapa sawit areal tumbang total berumur 4,5 tahun.

Penelitian ini mengguakan metode survey pada areal tanaman kelapa sawit. Lokasi penelitian ini dipilih secara sengaja, karena pada lokasi tersebut terdapat perkebunan tanaman kelapa sawit areal sistem peremajaan tumbang serempak dan areal sistem peremajaan sisipan.

Peubah yang diamati dalam penelitian ini adalah peubah fisik tanaman meliputi ; tinggi batang, lingkar batang, dan warna daun, serta peubah produksi (berat TBS, jumlah TBS, dan jumlah bunga betina). Kemudian peubah tambahan meliputi $\mathrm{pH}$ tanah, intensitas cahaya, suhu, dan kelembapan udara. Data tindakan agronomi pada kedua lokasi ini diperoleh melalui wawancara terpimpin yang dipandu oleh kuisioner.

\section{HASIL DAN PEMBAHASAN}

Hasil pengamatan lapangan, sistem peremajaan kelapa sawit tumbang serempak dan sistem peremajaan sisipan berpengaruh nyata terhadap peubah fisik diantaranya tinggi batang, lingkar batang, berat TBS, jumlah TBS, jumlah bunga betina, warna daun dan peubah lingkungan tanaman kelapa sawit seperti $\mathrm{pH}$ tanah, intensitas cahaya, suhu, dan kelembapan udara. Hasil uji independent t-test dapat dilihat pada Tabel 1.

Tabel 1. Rerata Peubah Fisik, Lingkungan Tanaman dan Produksi Kelapa Sawit Sistem Peremajaan Tumbang Serempak dan Sistem Peremajaan Sisipan.

\begin{tabular}{rccc}
\hline \multirow{2}{*}{ A.Peubah Fisik } & \multicolumn{2}{c}{ Sistem Peremajaan } & \multirow{2}{*}{ Sig. } \\
\cline { 2 - 3 } & Tumbang Serempak & Sisipan & \\
\hline 1. Tinggi batang hingga titik buah tertinggi $(\mathrm{cm})$ & 102,88 & 110,17 & 0,000 \\
1. Lingkar Batang (m) & 2,3507 & 2,3502 & 0,266 \\
2. Berat TBS (kg) & 6,299 & 3,827 & 0,000 \\
3. Jumlah TBS (Buah) & 10,96 & 8,53 & 0,000 \\
4. Jumlah Bunga Betina (buah) & 2,09 & 1,64 & 0,000 \\
5. Warna daun & Hijau muda & Hijau tua & 0,000 \\
B. Peubah Lingkungan: & & & \\
1. pH Tanah & 6,01 & 5,51 & 0,000 \\
2. Intensitas Cahaya (kaki lilin) & 442,40 & 401,33 & 0,000 \\
3. Suhu Rata-rata ( $\left.{ }^{\circ} \mathrm{C}\right)$ & 31,00 & 30,43 & 0,000 \\
4. Kelembaban $(\%)$ & 69,33 & 70,50 & 0,000 \\
\hline
\end{tabular}

Keterangan : $p \geq 0,05$ berbeda tidak nyata menurut uji independent t-test $\alpha 5 \%$

Dari Tabel 1 terlihat bahwa sistem peremajaan tumbang serempak menghasilkan berat tandan buah segar (TBS), jumlah TBS, serta jumlah bunga betina lebih tinggi dibanding kelapa sawit sistem peremajaan sisipan, berturut-turut $64,59 \%, 28,49 \%$, serta $27,44 \%$. Perbedaan juga terjadi pada tinggi batang dan warna daun, tetapi lingkar batang relatif sama. Peubah lingkungan seperti $\mathrm{pH}$ tanah, intensitas cahaya, suhu rata-rata dan kelembaban udara lahan tanaman kelapa sawit sistem peremajaan tumbang serempak juga menunjukkan perbedaan dengan lahan tanaman kelapa sawit sistem peremajaan sisipan.

Berdasarkan hasil wawancara langsung di lapangan terdapat perbedaan tindakan agronomi antara petani yang menerapkan sistem peremajaan tumbang serempak dan sistem peremajaan sisipan. Perbedaan tindakan agronomi yang dilakukan dapat dilihat pada Tabel 2 . 
Nasamsir dan Edi Romadoni. Produksi Kelapa Sawit (Elais guineensis Jacq.) Dengan Peremajaan Tumbang Total dan Sisipan

Tabel 2.Tindakan Agronomi Petani Sistem Peremajaan Tumbang Serempak dan Sistem Peremajaan Sisipan

\begin{tabular}{lccc}
\hline \multirow{2}{*}{ Tindakan Agronomi } & \multicolumn{2}{c}{ Sistem Peremajaan } & \multirow{2}{*}{ Keterangan } \\
\cline { 2 - 3 } & Tumbang Serempak & Sisipan & beda \\
Luas Areal (Ha) & 6 & 10 & sama \\
Jenis Tanaman & Tenera & Tenera & beda \\
Umur Tanaman (tahun) & 4,5 & 5,5 & beda \\
Jarak Tanam (m) & $8-9$ & $9-9,5$ & sama \\
Kendala Pemanenan & Tidak ada & Tidak ada & sama \\
Berapa kali Pemanenan & 2 & 2 & sama \\
Pemupukan & Ya & Ya & beda \\
Berapa Kali Pemupukan & Sekali 4 bulan & Sekali 3 bulan & beda \\
Berapa Produksi (ton/tahun) & $1,4-1,6$ & $0,6-0,8$ & beda \\
Kenapa Melakuan TS/Sisipan & Hasil besar & Tidak ada dana & sama \\
Waktu Pengendalian Penyakit & Tidak ada & Tidak ada & sama \\
Pengendalian gulma & Ada & Ada & beda \\
Cara Pengendalian gulma & kimiawi & mekanis & \\
\hline
\end{tabular}

Dari Tabel 1 dapat dilihat bahwa kondisi lingkungan di kedua lokasi areal kelapa sawit yang diteliti, seperti pH tanah, suhu, dan kelembaban udara dilihat dari angka hasil pengukuran tidak terlalu besar perbedaanya, kecuali untuk intensitas cahaya matahari di lahan kelapa sawit sistem peremajaan tumbang serempak lebih tinggi dibandingkan lahan sistem peremajaan sisipan. Lebih tingginya intensitas cahaya matahari pada lahan tumbang serempak, memberi peluang proses fotositesis lebih optimum sehingga produksi TBS kelapa sawit tumbang serempak akan lebih tinggi.

Berat TBS, jumlah TBS per pohon, dan jumlah bunga betina per pohon lebih tinggi pada kebun sistem peremajaan tumbang serempak dari kebun sistem peremajaan sisipan, hal ini terjadi karena kelapa sawit yang ditanam dengan sistem tumbung serempak pertumbuhanya lebih baik pada fase awal pertumbuhan setelah di lapangan karena tanaman tersebut tidak mengalami persaingan penyerapan unsur hara, air, dan intensitas cahaya matahari. Dengan demikian, pertumbuhan awal kelapa sawit dengan sistem peremajaan tumbang serempak yang lebih baik akan menghasilkan produksi yang lebih tinggi dibanding sistem peremajaan sisipan.

Dari Tabel 1 dapat juga dilihat tinggi batang hingga titik tertinggi buah pada tanaman kelapa sawit sistem peremajaan sisipan lebih tinggi dibanding tanaman kelapa sawit sistem peremajaan tumbang serempak. Hal ini diduga terjadi karena sejak awal pertumbuhan bibit tanaman kelapa sawit di lapangan pada sistem peremajaan sisipan terjadi persaingan terhadap cahaya matahari, karena di sekitar bibit tanaman kelapa sawit sisipan yang ditanam, masih terdapat tanaman kelapa sawit tua. Gtuneland dalam Nasamsir dan Indrayadi (2016) dijelaskan, intensitas cahaya yang rendah pada lahan sistem peremajaan sisipan menyebabkan ketebalan daun lebih tebal, dan berwarna lebih gelap. Persaingan terhadap cahaya matahari, unsur hara dan air pada tanaman kelapa sawit sistem peremajaan sisipan masih terjadi dalam kurun waktu relatif lama sampai tanaman kelapa sawit tua mati dengan sendirinya. Lebih tingginya tanaman kelapa sawit pada perkebunan dengan sistem peremajaan sisipan juga diduga karena terjadinya etiolasi karena adanya naungan dari tanaman tua yang masih ada. Tanaman yang mengalami cekaman kekurangan cahaya akan mengalami etiolasi yang disebabkan karena auksin yang tidak terurai dan aktif memperbesar dan memperpanjang sel lebih cepat (Gardner, Pearce dan Mitchell, 1991)

Pola peremajaan sawit rakyat secara tebang bertahap $20 \%$ menyebabkan tanaman sawit muda mengalami etiolasi sehingga pertumbuhannya kurang baik dibanding pola peremajaan bertahap $40 \%$ dan $60 \%$ (Herman dan Pranowo, 2011).

Persaingan juga terjadi antara kelapa sawit sisipan dan gulma yang relatif banyak dan beragam yang mengakibatkan pertumbuhan kelapa sawit pada lahan sistem peremajaan sisipan menjadi kurang optimal dan hal ini berdampak terhadap rendahnya produksi kelapa sawit di lahan sistem peremajaan sisipan.

Untuk mengurangi dampak kompetisi penyerapan unsur hara pada sistem peremajaan sisipan, diperlukan usaha peningkatan kesuburan tanah melalui pemupukan sehingga ketersediaan unsur hara dapat mencukupi kebutuhan tanaman kelapa sawit. Hasil penelitian Parulian, Gunawan, dan Arief (2013), pemberian pupuk organik dan NPK dapat meningkatkan pertumbuhan tanaman kelapa sawit hasil peremajaan sisipan.

Dari Tabel 2 dapat dijelaskan bahwa tindakan agronomi petani seperti frekuensi pemupukan di lahan kelapa sawit sistem peremajaan sisipan lebih banyak dibandingkan sistem peremajaan tumbang serempak, tetapi produksi kelapa sawit pada lahan sistem peremajaan tumbang serempak lebih tinggi. Jarak tanam kelapa sawit lebih jarang pada areal sistem peremajaan sisipan, hal ini berdampak pada produksi TBS per bulan per hektar kelapa sawit lahan 
Nasamsir dan Edi Romadoni. Produksi Kelapa Sawit (Elais guineensis Jacq.) Dengan Peremajaan Tumbang Total dan Sisipan

sistem peremajaan sisipan lebih rendah dibandingkan dengan produksi TBS kelapa sawit tumbang total karena jumlah tanaman per hektar yang sedikit.

\section{KESIMPULAN} berikut:

Berdasarkan hasil penelitain dan pembahasan yang telah diuraikan, maka dapat diambil kesimpulan sebagai

Produksi tandan buah segar kelapa sawit sistem peremajaan tumbang serempak lebih tinggi dibandingkan sistem peremajaan sisipan.

Hasil analisis uji t juga menunjukkan terdapat perbedaan tanaman kelapa sawit antara sistem peremajaan tumbang serempak dengan sistem sisipan, yaitu tinggi batang $(102,88 \mathrm{~m}: 110,17 \mathrm{~m})$, berat TBS $(6,299 \mathrm{~kg}: 3,827$ $\mathrm{kg}$ ), jumlah TBS per pohon (10,96 Buah : 8,53 buah), jumlah bunga betina per pohon (2,09 buah : 1,64 buah) dan perbedaan kondisi lingkungan.

\section{DAFTAR PUSTAKA}

Direktorat Jenderal Perkebunan Kementerian Petanian RI, 2018. Laporan Tahunan Sektor Perkebunan Nasional. Kementrian Pertanian RI. Jakarta

Gardner, F.B., R.B. Pearce, dan R.L. Mitchell. 1985. Fisologi Tanaman Budidaya. Terjemahan H. Susilo. UI-Press. Jakarta. 1991

Herman, M dan D. Pranowo. 2011. Produktivitas Jagung Sebagai Tanaman Sela pada Peremajaan Sawit Rakyat Di Bagan Sapta Permai Riau.Seminar Nasional Serealia 2011.

Nasution, S.H., C. Hanum, J. Ginting, 2014. Pertumbuhan Bibit Kelapa Sawit (Elaeis guinensis Jacq.) Pada Berbagai Perbandingan Media Tanam Solid Decanter dan Tandan Kosong Kelapa Sawit Pada Sistem Single Stage. Jur. online Agroteknologi. Vol.2 No.2. 2014. USU Medan.

Nasamsir dan Indrayadi, M., 2016. Karakteristik Fisik Dan Produksi Kelapa Sawit (Elaeis Guineensis Jacq.) Pada Tiga Agroekologi Lahan Karakteristik Fisik Dan Produksi Kelapa Sawit (Elaeis Guineensis Jacq.) Pada Tiga Agroekologi Lahan. Jur. Media Pertanian. Vol.1(2) 2016. Fak. Pertanian Univ. Batanghari.

Parulian, A.S, J. Gunawan, dan F.B. Arief, 2013. Evaluasi Kesuburan Tanah Untuk Replanting Kelapa Sawit di Afdeling I (satu) PTPN XIII Kabupaten Landak. Jur. Sains Mahasiswa Pertanian.Vol. 2(2). Fak. Pertanian Univ. Tanjungpura.

Sukamto. 2008. Kiat Meningkatkan Produktivitas dan Mutu Kelapa Sawit. Penebar Swadaya. Jakarta. 